\title{
Critical Theory and Security Studies
}

Keith Krause

YCISS Occasional Paper Number 33

February 1996 


\section{Keith Krause ${ }^{1}$ \\ Graduate Institute of International Studies, Geneva}

\section{Introduction}

Security studies has been among the last bastions of neorealist orthodoxy in International Relations to accept critical, or even theoretically-sophisticated, challenges to its problematic. Recent polemical exchanges in the security studies literature have, however, at least linked the term "critical theory" with security studies, and although they do not necessarily advance the debate, they at least raise the question: what is a critical approach to security studies? My goal in this paper is not to invoke a new orthodoxy of "critical security studies" or to participate in polemical recriminations, but to illustrate what a critical engagement with issues and questions that have been taken as the subject matter of security studies involves. I do this in several steps:

a) a review of the (brief) debate in security studies concerning the contributions of "critical" scholarship;

b) a presentation of the intellectual "foundations" of critical approaches to International Relations;

c) an overview of current research within "critical security studies" that illustrates its ability to generate a challenging and productive research agenda;

d) a discussion of the intellectual and disciplining power of mainstream security scholarship, and the difficulties this poses for critical challenges. ${ }^{2}$

What I will not do is present a critique of traditional research and theory in security studies, except to highlight some of the conclusions of this critique. ${ }^{3}$ Since one of the main accusations levelled against critical theory (at least in International Relations) is that it cannot get "beyond critique," I

\footnotetext{
${ }^{1}$ DRAFT ONLY, COMMENTS WELCOME, DO NOT CITE WITHOUT PERMISSION. Parts of this paper draw upon previous writing and research I have done with Michael C. Williams on critical security studies.

${ }^{2}$ I am using "mainstream," "traditional," "orthodox" and "neorealist" approaches to security studies interchangeably in this essay.

${ }^{3}$ We have, however, attempted to do this in Keith Krause and Michael C. Williams, "Politics and Method in Contemporary Security Studies," unpublished paper, 1996, and in "From Strategy to Security: Foundations of Critical Security Studies," in Keith Krause and Michael C. Williams, eds., Critical Security Studies: Concepts and Cases (Minneapolis: University of Minnesota Press, forthcoming).
} 
intend to demonstrate that one can find lurking in the interstices of the discipline a wide range of critical scholarship and research that is "about" security (and its core subject matter), but which its authors, or the discipline, refuses to label as such. Simply bringing together these perspectives makes the challenges to orthodoxy more clear, and signals that critical approaches to security studies are more than a passing fad or the idiosyncratic obsession of a few scholars.

Ultimately, this is healthy for security studies as a whole. Security studies continues to be treated by many scholars as a theoretically-impoverished cousin to the sturdy children of International Relations, which could include (depending on your preference) liberal and radical approaches to International Political Economy, neoliberal institutionalist analyses, regime theory, foreign policy analysis and so forth. ${ }^{4}$ Debate among competing approaches, and a greater conceptual clarity, can only strengthen the claims of security studies scholars for intellectual respect. What is more, it is possible to argue that far from falling into desuetude with the end of the Cold War, many of the most interesting theoretical issues in International Relations - concerning, for example, identity politics and communal conflict, multilateral security institutions, the development of norms and practices, and so-called new issues (such as the environment) - can be most usefully studied through a prism labelled "security studies."

\section{Who's Who and What's in a Label?}

An irresistible starting point for this discussion is John Mearsheimer's presentation of "critical theory" in the context of his discussion of the "False Promise of International Institutions." His "who's who" of critical theorists in International Relations includes Richard Ashley, Robert Cox, Friedrich Kratochwil, John Ruggie, Yosef Lapid, Alexander Wendt, and perhaps Emanuel Adler, Richard Ned Lebow and Thomas Risse-Kappen. ${ }^{5}$ Of course, this list is not exhaustive, and as Alexander Wendt points out, it blurs important distinctions between post-modernist, constructivist, neo-Marxist and feminist scholars (in fact it ignores scholarship in some of these camps). ${ }^{6}$ Perhaps Mearsheimer is right: the shared assumptions of these scholars may be greater than their differences (and one is reminded of the

\footnotetext{
${ }^{4}$ For an excellent example of this see David Baldwin, "Security Studies and the End of the Cold War," World Politics, 48 (1995), 117-141, who concludes by arguing that security studies should be reincorporated into international relations or foreign policy analysis.

${ }^{5}$ These are taken from his footnotes. John Mearsheimer, "The False Promise of International Institutions," International Security, 19:3 (Winter 1994/95), 37-47.

${ }^{6}$ Alexander Wendt, "Constructing International Politics," International Security, 20:1 (Summer 1995), 71.
} 
response to a broad characterization of neorealist scholarship that critics such as Ashley have presented). Their shared assumptions are not, however, what Mearsheimer thinks they are, and his choice of exemplars betrays a different purpose (which I will discuss below). Here I want to highlight one other feature of Mearsheimer's discussion: he does not cite any research that has been done under his critical label (an error he does not make with other approaches), and he claims that "critical theorists have yet to provide evidence that their theory can explain very much...the distinguishing feature of the critical theory literature...is its lack of empirical content."7

Aside from his sloppiness with respect to research in critical International Relations, there could be three possible reasons (or some combination thereof) for presenting the sort of review and dismissal of other approaches that Mearsheimer offers. The first would be a belief that the differences between critical and other approaches can be arbitrated (and the most appropriate approach selected) in an a priori or logical deductive fashion. Mearsheimer's review steers perilously close to this in his presentation of what he calls the "realist world" when what are assumptions of a realist theory start to sound like descriptions of an actual world, which critical theory can somehow not explain. This is especially manifest when he asserts that "realism was the dominant discourse from about the start of the late medieval period in 1300 to at least 1989." ${ }^{8}$ Aside from the curious use of "discourse," no serious scholar working in a rationalist paradigm would make the error of confusing the assumptions of the theory, and the explanatory hypotheses these can generate, with the workings of the world. Critical International Relations can (and does) offer an account of different features of these 700 years of history, and does not exclude the possibility of "critical realist" explanations. ${ }^{9}$

The second reason might be the assumption that the ultimate test of our theories is some external and objective reality against which they stand or fall. As Mearsheimer claims, "Realists maintain that there is an objective and knowable world, which is separate from the observing individual." 10 This approach is self-contradictory, and fundamentally misunderstands the role of theory in "constructing" what we see and how we see it - which Mearsheimer seems (if inadvertently) to

\footnotetext{
${ }^{7}$ John Mearsheimer, "A Realist Reply," International Security, 29:1 (Summer 1995), 92. A related (and more complex) claim that I cannot fully counter here is that "the research practices of scholars like Ruggie, Kratochwil and others identified with constructivist or interpretive approaches converge substantially with those advocated by mainstream scholars... [and] methodological differences appear to be small -- or at least are not clearly conceptualized, specified and articulated in the literature." Ronald Jepperson, Alexander Wendt and Peter Katzenstein, "Norms, Identity, and State Security in the Contemporary World System," unpublished paper, 1994.

${ }^{8}$ Mearsheimer, "False Promise," 44.

${ }^{9}$ A label used, for example, by Robert Cox.

${ }^{10}$ Mearsheimer, "False Promise," 41.
} 
recognize elsewhere when he says that "the debate is over which theory provides the best guide to understanding state behavior." ${ }^{11}$ If reality is objectively knowable, then why do we need to construct theories to organize or explain phenomena that present themselves to us? Conversely, if theories tell us what to look for (and more importantly, how to organize disparate phenomena under labels such as "bandwagoning" or "balancing," or "deterring" and "compelling") then reality is not "objectively" knowable without being mediated via theories. Suddenly the choice of theoretical lenses becomes important!

The third assumption could be that there is only one "set" of things to be explained by International Relations, and that therefore critical approaches are judged by how well they (for example) account for 700 years (or more) of ceaseless competition between states. This follows Martin Wight's description of International Relations as the "realm of recurrence and repetition," and effectively denies that a social theory of world politics has any subject matter. ${ }^{12}$ But it is possible that critical and neorealist approaches represent incommensurable positions towards International Relations (or security studies), and hence that there is no "neutral" point from which disagreements can be arbitrated. The best one can hope for is to make a choice, dependent on what it is one is trying to explain, and what one thinks are the appropriate means to go about this. Although Mearsheimer seems to think this difference represents a trumping of ethical preferences or values over scholarly commitments, instead it represents a set of choices on a different level (which is where the debate must be engaged). ${ }^{13}$

Finally, I should register the obvious caveats over the use of the term "critical." Its use as an umbrella term to describe all work that falls outside of the rationalist (neoliberal and neorealist) paradigm does some violence to the intellectual origins of the term, in the German (Frankfurt) tradition of critique associated with contemporary thinkers such as Jürgen Habermas. This tradition does not

\footnotetext{
${ }^{11}$ Mearsheimer, "A Realist Reply," 90.

${ }^{12}$ Martin Wight, "Why is There No International Theory?" in Herbert Butterfield and Martin Wight, eds., Diplomatic Investigations: Essays on the Theory of International Politics (London: Unwin, 1966), 17-34.

${ }^{13}$ See Mearsheimer, "False Promise," 39, 41; but see 44, where he claims that critical theorists' "communitarian discourse" is "not an outcome linked to the theory itself." It would be easy for me to argue that both positions rest ultimately on ethical choices that cannot be arbitrated, but I think this is a mistaken strategy. Instead, I would argue that the two "modes" of scholarship I outline in this paper are related, and that "there are not two methods, the explanatory method and the method of understanding...Understanding precedes, accompanies, closes and thus envelops explanation. In return, explanation develops understanding analytically." Paul Ricoeur, "Explanation and Understanding: On Some Remarkable Connections Among the Theory of the Text, Theory of Action, and Theory of History," in Charles Reagan and David Stewart, eds., The Philosophy of Paul Ricoeur (Boston: Beacon Press, 1978), 165.
} 
include the radically different ideas that emerge from post-structuralist or post-modernist projects (and in fact, it is resolutely modernist in its rejection of them), but does present itself as an alternative to rationalist social science. Perhaps the biggest problem, however, is that the very term critical in English contains no connotations of a positive or reconstructive project, and allows both proponents and opponents to stop at the theoretical level, without reflecting on the practical implications of this scholarship. This is certainly not my intention. In what follows, I do not intend to parse the widely divergent claims that are made by scholars working in a critical tradition. I do hope, however to demonstrate, contra Mearsheimer, that there is much high quality critical research, that it is capable of expanding our understanding of world politics, and that it needs to be understood on its own terms as presenting a serious alternative to rationalist, neorealist, scholarship in security studies.

\section{Foundational Claims of Critical International Relations}

There are six foundational claims at the core of critical approaches to International Relations, which can be summarized as follows:

- the principle actors (subjects) in world politics - whether these are states or not - are social constructs, and products of complex historical processes that include social, political, material and ideational dimensions;

- these subjects are constituted (and reconstituted) through political practices that create shared social understandings; this process of constitution endows the subjects with identities and interests (which are not "given" or unchanging);

- world politics is not static and unchanging, and its "structures" are not determining, since they are also ultimately socially constructed;

- our knowledge of the subjects, structures and practices of world politics is not "objective," since there exists no objective world separate from the collective construction of it by observers or actors;

- the appropriate methodology for the social sciences is not that of the natural sciences, and there is no methodological unity of science. Interpretive methods that attempt to uncover actors' understandings of the organization (and possibilities) of their social world are the central focus of research;

- the purpose of theory is not prediction (control) or the construction of transhistorical, generalizable causal claims; contextual understanding and practical knowledge is the appropriate goal. 
These claims have deep philosophic roots, and different scholars would "sign on" to them claims in different degrees, but they pose a sharp contrast to neorealist or neoliberal scholarship in International Relations. ${ }^{14}$ One convenient way to highlight this contrast is Roxanne Doty's distinction between "how" and "why" questions. The latter are concerned "with explaining why particular decisions resulting in specific courses of action were made," the former with "how the subjects, objects, and interpretive dispositions were socially constructed such that certain practices were made possible." ${ }^{15}$ Most importantly, "how" questions are logically prior to "why" questions: before particular courses of action can be selected, the range of possible or plausible options has to be constructed, and scholars have to understand the way in which certain options (such as "maintaining reputation," or "gaining prestige") acquire meaning or value. In security studies (as I will discuss below), this involves constructing the nature (and source) of threats, the "object" being secured, and the possibilities for reinforcing, ameliorating or even overcoming "security dilemmas." Traditional approaches take all of these issues as givens.

Behind each of these claims lies a set of arguments too large to explore here. But I can at least close off some common avenues of objection by demonstrating with a few examples what these claims do not imply. Unfortunately, the most insidious counter-arguments mounted against critical theories (which some scholars occasionally play into) usually involve linking some or all of these claims to other, ancillary, propositions that are not a necessary part of the core of critical theoretical approaches. It is as if the advocacy of nuclearization for Germany were counted as compelling evidence against neorealism, or the use of formal modelling techniques taken as a criticism of institutionalist theory.

The first "red herring" is the argument that critical theorists understate, ignore or "wish away" the importance of the state. In no way does the claim that the principle institutions of world politics are socially constructed imply this. Many critical scholars recognize that the state (or at least the state system) has reached a historical high point, and that it presents a powerful object of loyalty and

\footnotetext{
${ }^{14}$ These can be contrasted with Robert Keohane's or Joseph Grieco's presentation of the central assumptions of realism, and with Kenneth Waltz's methodological stance. See the two essays by Robert Keohane in Robert Keohane, ed., Neorealism and its Critics (New York: Columbia University Press, 1986); Joseph Grieco, "Anarchy and the Limits of Cooperation: A Realist Critique of the Newest Liberal Institutionalism," International Organization, 42 (1988), 485507, and Kenneth Waltz, Theory of International Politics (Reading, Mass.: Addison-Wesley, 1979). For a profile of the roots of critical theory see Richard Bernstein, The Restructuring of Social and Political Theory (London: Methuen, 1979); Fred Dallmayr and Thomas McCarthy, eds., Understanding and Social Inquiry ( Indiana: University of Notre Dame Press, 1977).

${ }^{15}$ Roxanne Doty, "Foreign Policy as Social Construction: A Post-positivist Analysis of U.S. Counterinsurgency Policy in the Philippines," International Studies Quarterly, 37:3 (September 1993), 298. Emphasis hers.
} 
aspiration that needs perhaps to be taken more seriously. ${ }^{16}$ Others are interested in examining the way in which the substantive and normative content of the concept of "state sovereignty" may have changed and be changing. ${ }^{17}$ Still others are interested in the transformation from the medieval to the modern, as a means of highlighting the ways in which the state was "constructed" out of the political, economic and ideational matrix of that period. ${ }^{18}$

A related claim suggests that critical theorists are committed to a belief that identities (whether state or individual) are infinitely malleable, and can be changed like sets of clothing. ${ }^{19}$ The most extreme version of this is the accusation that critical approaches represent pure "idealism" - the belief that ideas are the driving force of history, and that if our ideas are simply changed, so too will be the world. This canard is the least fair of all, as even Mearsheimer recognizes in a footnote $!^{20}$ It misinterprets the argument that the process of constituting political subjects (such as states) endows them with identities and interests that are not just "given." The only claim advanced here is that interests must be "endogenized" in our theories (Wendt's term), or rather, that the "interests" of political subjects such as states are not given by structures, but are generated by social processes of interaction between them. ${ }^{21}$ More importantly for critical International Relations, since the state is an "abstraction" or construct (states don't choose, people do), the process of endowing states with interests is a social

\footnotetext{
${ }^{16}$ See, for example, R.B.J. Walker, "Security, Sovereignty and the Challenge of World Politics," Alternatives, 15 (1990), 3-27; Mohammed Ayoob, "Defining Security: A Subaltern Realist Perspective," in Krause and Wiliams, Critical Security Studies.
}

${ }^{17}$ J. Samuel Barkin and Bruce Cronin, "The State and the Nation: Changing Norms and the Rules of Sovereignty in International Relations," International Organization, 48:1 (Winter 1994), 107-130; Thomas Biersteker and Cynthia Weber, The Social Construction of Sovereignty (Cambridge: Cambridge University Press, forthcoming).

${ }^{18}$ This is by no means confined to critical scholarship. See Rodney Bruce Hall and Friedrich Kratochwil, "Medieval Tales: Neo-Realist "Science" and the Abuse of History," International Organization (1993) 47, 479-500; Jeff Holzegrefe, "The Origins of Modern International Relations Theory," Review of International Studies, 15 (1989), 11-26; Ronald Diebert, "Typographica: The Medium and the Medieval-to-Modern Transformation," Review of International Studies, 22:1 (January 1996), 29-56; John Ruggie, "Continuity and Transformation in the World Polity: Toward a Neorealist Synthesis," in Keohane, ed., Neorealism and Its Critics, 131-157.

${ }^{19}$ As he puts it, "the key...is to alter state identity radically or more specifically, to transform how states think about themselves and their relationship with other states...states must stop thinking of themselves as solitary egoists, and instead develop a powerful communitarian ethos." Mearsheimer, "False Promise," 39, 41.

${ }^{20}$ Mearsheimer, "False Promise," 40n. In spite of this footnote, however, his prose elsewhere (pp. 37-38) betrays his suspicions.

${ }^{21}$ Alexander Wendt, "Collective Identity Formation and the International State," American Political Science Review 88 (1994), 384-396. This is not as far from Waltzian structuralism as some might think, since even Waltz admits that structures only "shape and shove," that "the shaping and shoving of structures may be successfully resisted," and that "states affect the system's structure even as it affects them." Waltz, "Reflections on Theory of International Politics: A Response to My Critics," in Neorealism and its Critics, 343, 331. Of course, this considerably weakens Waltz's theory. 
one, whereby particular sets of individuals advocate and develop common understandings of interests in order to motivate collective social action (under the heading of "foreign policy, for example). Thus integration theory, for example, would focus attention on the interaction between France and Germany, and the process whereby the relevant elites (perhaps even the entire population) began to reconceptualize their interests as "Europeans" in ways that excluded the possibility of violent conflict between their "states."22 No one, however, would claim that this is either a simple or an easy process only that a realist acceptance of state interests as given completely excludes (by definition) study of this issue.

A third "red herring" that attacks critical methodology accuses it of "subjectivism," colloquially presented as the "anything goes" argument. Mearsheimer latches onto this when he quotes Richard Ashley to the effect that "there are no constants, no fixed meanings, no secure grounds, no profound secrets, no final structures or limits to history...there is only interpretation."23 It must be acknowledged that some variants (most often labelled post-modern) of critical scholarship would adopt an "anything goes" position (and argue that all interpretations are arbitrary), but most scholars would not. The acceptance that our knowledge (as scholars) of the subjects, structures and practices of world politics is not "objective," does not even lead all scholars to a rejection of naturalist models for science. Some, such as Alex Wendt or Michael Barnett, "fully endorse the scientific project of falsifying theories against evidence." ${ }^{24}$ Others accept neither Ashley's nor Wendt's position, and argue that although social science should not emulate the methodology of the natural sciences, their commitment to an interpretive method does not imply rejection of the idea that there are better or worse interpretations only a rejection of the idea that they are arbitrated against some external "reality" rather than against social actors' understandings of their world. ${ }^{25}$

\footnotetext{
${ }^{22}$ I am not, of course, arguing that integration theorists are critical theorists, but some (such as Emanuel Adler) would adopt a constructivist orientation.

${ }^{23}$ Mearsheimer, "False Promise," 41.

${ }^{24}$ Wendt, "Constructing," 75. I hesitate here, because for many this methodological point is what separates critical from other scholarship, and might (depending on what "falsifying theories against evidence means") place Wendt outside the camp. In any case, it is clear that Wendt's version of constructivism is the most conservative and "tame" critical alternative - which might explain its "admissibility."

${ }^{25}$ In fact, it is quite possible to point out how allegedly "scientific" scholarship also rests inescapably on interpretations. See Krause and Williams, "Politics and Method." See also Mark Neufeld, "Interpretation and the 'Science' of International Relations," Review of International Studies. 19 (1993), 39-62; Martin Martin Hollis and Steve Smith, Explaining and Understanding International Relations (Oxford: Oxford University Press, 1991).
} 
The fourth point concerns stasis and change, and illustrates the "what you look for is what you see" nature of realist arguments. A realist casts his or her eye over 700 years of history and sees a ceaseless repetition of state competition for power, suspicion and insecurity. Some even go further back, and interpret the medieval world, or the world of Greek city-states, in similar terms. But when these claims are examined closely, they often turn out to rest upon tendentious or implausible readings of history that are little better than Whig or Toynbee-esque versions. ${ }^{26}$ The fallback position - that neorealists are not trying to make determinate predictions, but are trying to construct transhistorical, generalizable causal claims in order to explain a small number of big things - does not obviate these problems. First, it assumes the possibility of transhistorical generalization - of uncovering some sort of "laws of history" - which historicist accounts deny, and which are in some disrepute in other fields of social science. ${ }^{27}$ Second, it opens the door for other (even critical) scholars to offer to account for a large number of perhaps equally important but "smaller" things. A critical or constructivist scholar sees over the 700 years of European history variation, change, evolution and decline. The rise and decline of absolutism, the rise of modern nationalism, imperialism, the advent of self-determination and decolonization, and recent claims for democracy and human rights have all embedded inter-state interactions in a complex web of ideas that gives practical (and shifting) content to understandings of interests. $^{28}$

This sort of contextual understanding and practical knowledge is what scholarship should aspire to, and since human agents are engaged in constructing their world (and their future), scientific models of explain-predict-control (the old Comte-ian formula) are at best misguided, and at worst pernicious. ${ }^{29}$ Hence it is no accident that Robert Cox, for example, eschews prediction, since he believes it neither possible nor desirable, except within a framework of "problem-solving theory" that takes the social and political order as fixed and works within this assumption via a determinist "if-then"

\footnotetext{
${ }^{26}$ See, for example, Paul Schroeder's analysis in "Historical Reality vs. Neorealist Theory," International Security, 19:1 (Summer 1994), 108-148, and the subsequent debate between him and Colin Elman and Miriam Fendius Elman in International Security, 20:1 (Summer 1995), 182-195. See also Laurie Bagby, "The Use and Abuse of Thucydides in International Relations," International Organization, 48:1 (Winter 1994), 131-153; Markus Fischer, "Feudal Europe, 800-1300: Communal Discourse and Conflictual Practices," International Organization, 46:2 (Spring 1992); Hall and Kratochwil.

${ }^{27}$ For a brilliant account of this sort of problem in a different discipline - paleontology - see Stephen Jay Gould, Wonderful Life (New York: Norton, 1989), especially 27-44, 277-291.

${ }^{28}$ See previous references to Barkin and Cronin; Hall and Kratochwil; Schroeder; John Ruggie, ed., Multilateralism Matters (New York: Columbia University Press, 1993).

${ }^{29}$ Brian Fay, Social Theory and Political Practice (London: George Allen and Unwin, 1975).
} 
logic that denies human agency. ${ }^{30}$ To claim then that a failure to make predictions is a weakness of critical theory is to miss the point entirely, and to evaluate it against other's goals.

Finally, and most importantly, the core assumptions of a critical approach do not commit one to a particular political position, except insofar as the acceptance that world politics is not static, and that its structures and identities are constructed, implies the possibility of change. One can easily conclude that socially constructed structures are deeply entrenched and unlikely to change rapidly, which is the position of a "critical realist" such as Robert Cox. Or it is possible to disagree radically on the forces that construct the social world - neo-Marxists such as Stephen Gill often fall back to material forces, while feminist scholars such as Carol Cohn or Sandra Whitworth would stress the gendered nature of social (including international) relations. ${ }^{31}$ This is not much different from the claim that neorealists and neoliberals differ on the importance of relative versus absolute gains, while remaining committed to a rationalist approach!

\section{Critical Security Studies}

What does all of this mean for security studies? The challenge faced by proponents of critical security studies is to present a coherent and intellectually robust research agenda that generates interesting debates and insights into the complexities and potentials of contemporary (and past) security issues. Space prevents me from a comprehensive review of all the literature that could be included under this umbrella; instead, I will highlight a variety of bodies of critical scholarship to demonstrate that there is an active and vibrant research community in critical security studies (although none of the authors I cite has been asked to wear this label!). I have organized this work under three headings: studies of the construction of "objects" of security; examinations of the construction of threats and appropriate responses; and evaluations of the possibilities for amelioration or transformation of security dilemmas. What I have not done is engage in a discussion of the appropriate methodology for critical security

\footnotetext{
${ }^{30}$ Robert Cox, "Social Forces, States and World Orders: Beyond International Relations Theory," in Keohane, Neorealism and its Critics, 208-210.

${ }^{31}$ Carol Cohn, "Sex and Death in the Rational World of Defense Intellectuals," Signs, 12:4 (1987), 687-718; Sandra Whitworth, "Gender, International Relations and the Case of the ILO," Review of International Studies, 20:4 (1994), 389-406.
} 
studies, and the way in which this may contrast with a rationalist approach; that task awaits another paper. $^{32}$

\section{The Obscure Object of Security}

The first body of literature inquires into how the object of security is constructed. A neorealist would find this question odd, for the object of security is the state, and national security (understood as the safeguarding of core values from forceful threats) the core concept. This is not a definitional move; casting the state as the guardian or custodian of values is a powerful resolution to central problems of political life. It begins with a "state of nature" account in which the individual subject is presented as an autonomous instrumentally-rational actor confronted by an environment filled with other like actors who represent a source of insecurity: hence the classic security dilemma. From this starting point, there can be no security in the absence of authority, the state becomes the primary locus of security, authority and obligation, and the security of "citizens" is identified with (and guaranteed by) that of the state. Those who stand outside the state represent potential or actual threats, and relations between states are thereby rendered purely "strategic" (or contractual), which provides the basis for claims about international "anarchy." 33 This account has its philosophical roots in "state of nature" analogies supposedly drawn from Hobbes or Rousseau, and in a contractarian vision of social life drawn from thinkers such as Locke. ${ }^{34}$

Perhaps the most straightforward challenge to this vision of the referent object of traditional security studies has been the effort to broaden its agenda to bring "new issues" such as environmental degradation, economic well-being, or migration and population into the discipline. ${ }^{35}$ This effort is not "critical" in any self-conscious sense, and does not challenge the philosophical underpinnings of the

\footnotetext{
${ }^{32}$ For an effort in this direction that demonstrates how weakly orthodox scholars adhere to the canons of rationalist science (and how close they may be to interpretive approaches!), see Krause and Williams, "Politics and Method."

${ }^{33}$ Grieco, "Anarchy," 497-498; Mearsheimer, "False Promise," 9-13; Helen Milner, "The Assumption of Anarchy in International Relations Theory: A Critique," in David Baldwin, ed., Neorealism and Neoliberalism: The Contemporary Debate (New York: Columbia University Press, 1993), 143-169.

${ }^{34}$ See Kenneth Waltz, Man, the State and War (New York: Columbia University Press, 1959); Michael C. Williams, "Rousseau, Realism and Realpolitik," Millennium, 18 (1989), 163-187; "Hobbes and International Relations: A Reconsideration," International Organization, (forthcoming 1996).

${ }^{35}$ Inter alia, see Caroline Thomas, In Search of Security: The Third World in International Relations (Boulder: Lynne Reinner, 1987); Theodore Moran, "International Economics and National Security," Foreign Affairs, 69:5 (Winter 1990/91), 74-90; Jessica Tuchman Mathews, 'Redefining Security,' Foreign Affairs, 68:2 (Spring 1989), 162-177; Brad Roberts, "Human Rights and International Security," Washington Quarterly, (Spring 1990), 65-75; Myron Weiner, "Security, Stability and International Migration," International Security, 17:3 (Winter 1992-93), 91-126. Richard Ullman, "Redefining Security," International Security, 8:1 (Summer 1983), 129-153.
} 
traditional vision; it simply asserts that (for example), environmental challenges "demand a redefinition of what constitutes national security [because]...the assumptions and institutions that have governed international relations in the postwar era are a poor fit with these new realities." ${ }^{16}$ The object of security should not, however, remain the state, since what is "really" threatened is not an abstraction like the state, but the material well-being of individuals, or the "ecosystem" itself. ${ }^{37}$ Only the constraints imposed by traditional categories of thought have limited our grasp of this reality, and hence our conceptions of security must change to meet new challenges. This argument also assumes (usually implicitly, sometimes explicitly) that the choice of which issues fall under the sign of security is in part a political one, and that one of the goals is to contest the definition of what counts as a security threat to the nation-state. ${ }^{38}$

Most of the research conducted into issues of environmental security, however, has been concerned with the potential for rapid environmental change or degradation to catalyze violent conflicts between states (or communal groups), and hence has not challenged directly the construction of the referent object of security. For example, researchers involved in projects on "Environmental Change and Acute Conflict" and "Environment, Population and Security" have attempted to assess the role of environmental scarcities in the outbreak of violent conflict. ${ }^{39}$ Peter Gleick and Miriam Lowi, for example, have placed access to and control of water as an aspect of "strategic rivalry" within an expanded conception of "geopolitical" conflict (in particular in the Middle East), while studies of the civil conflict in Rwanda and of the relationship between urban growth and violence have sought to determine the extent of links between scarcity and varying forms of violent conflict. ${ }^{40}$ Even so, by

${ }^{36}$ Tuchman Mathews, 162.

${ }^{37}$ Norman Myers, Ultimate Security: The Environmental Basis of Political Stability (New York: Norton, 1993), 31; Patricia Mische, "Ecological Security and the Need to Reconceptualize Sovereignty. Alternatives, 14 (1989), 389-427; Monica Tennberg, "Risky Business: Defining the Concept of Environmental Security," Cooperation and Conflict, $30: 3$ (1995), 239-258.

${ }^{38}$ For a critique of this from the environmentalist's side, see Daniel Deudney, "The Case Against Linking Environmental Degradation and National Security," Millennium 19:3 (1990), 161-176.

${ }^{39}$ Thomas Homer-Dixon, "On the Threshold: Environmental Changes as Causes of Acute Conflict," International Security, 16 (1991), 76-116; "Environmental Scarcities and Violent Conflict: Evidence from Cases," International Security 19 (1994), 5-40.

${ }^{40}$ Peter Gleick, "Water and Conflict: Fresh Water Resources and International Security," International Security, 18:1 (Summer 1993), 79-112; Miriam Lowi, "Bridging the Divide: Transboundary Resource Disputes and the Case of West Bank Water," International Security, 18:1 (Summer 1993), 113-138; Valerie Percival and Thomas Homer-Dixon, Environmental Scarcity and Violent Conflict: The Case of Rwanda, Project on Environment, Population and Security, University of Toronto, 1995; Peter Gizewski and Thomas Homer-Dixon, Urban Growth and Violence: Will the Future Resemble the Past?, Project on Environment, Population and Security, University of Toronto, 1995. 
reorienting analysis away from relations between the military forces of states (and classical security dilemmas) to the underlying dynamics that can serve as the sources of interstate conflict, this research responds to David Baldwin's observation that during the Cold War "the study of national security grew more narrow and rigid during the Cold War than it had been before," and that it "militarized the study of security" in ways that occluded a rich tradition of thought on "the nature, causes, effects and prevention of war. ${ }^{41}$

A more complex (and self-consciously critical) challenge that takes (implicitly or explicitly) women as the "object" of study (if not of security) has been posed by scholars such as Cynthia Enloe, writing on gender and security issues. Without resorting to essentialist arguments about differences between men and women, Enloe draws attention to the ways in which policies and practices under the rubric of "security" have a specific impact on women, enmeshing them in a web of violence, subordination and insecurity; and the way in which women's definitions of security may be more multidimensional or may challenge the notions of identity at the core of the state-centric vision. ${ }^{42}$ One response from orthodox scholarship is that this work does not challenge the central problematic of security studies - the causes of war and conditions of peace - but focuses on its consequences, which is a different issue. But in a constructivist logic, causes, conditions and consequences are not so easily separable. Enloe, for example, does not simply discuss the impact of American military bases on Philippine women, but is making a stronger claim about how such an organization of social relations is a crucial part of what makes the projection of American military might possible. Second, a gendered analysis is intended, at its most profound levels, to challenge the orthodox construction of the "object" of security (the state) by examining the ontological underpinnings of neorealist International Relations. ${ }^{43}$ Attempts to redefine the object of security from a gendered perspective do, however, have to confront the ways in which women (and men) have historically identified themselves also (perhaps

\footnotetext{
${ }^{41}$ Baldwin, "Security Studies and the End of the Cold War," 119, 125.

${ }^{42}$ Cynthia Enloe, Bananas, Beaches and Bases: Making Feminist Sense of International Politics (London: Pandora, 1989); The Morning After: Sexual Politics at the End of the Cold War (Berkeley: University of California Press, 1993). For Enloe, as for many feminist International Relations scholars, security is subordinated to an overall assessment of the practices of world politics.

${ }^{43}$ See, for example, J. Ann Tickner, Gender in International Relations: Feminist Perspectives on Achieving Global Security (New York: Columbia University Press, 1992).
} 
even primarily) as "citizens" and have participated in the state-centric discourses of security, sacrifice and war to which a gendered analysis draws attention. ${ }^{44}$

Other attempts to address this last issue have focused on how national security, identity, and interests have been constructed and defined, and on the "discourses of danger" that have been used to secure a society's collective identity in the modern world. David Campbell's monograph on American security, for example, explores the way in which the "self-other" dichotomy (which has been challenged from many quarters as overly-simplistic), meets the need of the state for "discourses of 'danger' to provide a new theology of truth about who and what 'we' are by highlighting who or what 'we' are not, and what 'we' have to fear." ${ }^{45}$ Similarly, Jutta Weldes takes seriously the concept of "national interest," but challenges the neorealist idea that threats to it are self-evident, and given from the capabilities of states. Her detailed research on the documentary record of the Cuban missile crisis demonstrates clearly that the installation of Soviet missiles in Cuba was not unproblematically understood as a threat to the United States; that this threat had to be constructed through a process of discussion and debate that contained many significant points of choice for the relevant decision makers. $^{46}$

A fourth assault on the state-centrism of traditional scholarship has been mounted by the socalled "Copenhagen school," which takes as its starting point the distinction between state and society. They argue that security studies needs to adopt an understanding of the "duality" of security: a combination of state security concerned with sovereignty and societal security concerned with identity. ${ }^{47}$ This idea of societal security places the origins, structures and dynamics of collective identity formation and the connection between identities and interests (and threats to them) at the heart of its

\footnotetext{
${ }^{44}$ See, for example, Jean Bethke Elshtain, "Sovereignty, Identity, Sacrifice," in V. Spike Peterson, ed., Gendered States (Boulder: Lynne Reinner, 1992), 141-154. Jean Elshtain, Women and War (New York: Basic Books, 1987). See also Rebecca Grant, "The Quagmire of Gender and International Relations," in V. Spike Peterson, ed., Gendered States (Boulder: Lynne Reinner, 1992), 83-97. Grant points out that the experience of women is not a sufficient foundation on which to construct a feminist epistemology (of security), but that the primary research goal of a feminist perspective should be "a better understanding of aspects of human behaviour that have been marginalized in theories of security" (pp. 94-95, 84, 87).

${ }^{45}$ David Campbell, Writing Security: United States Foreign Policy and the Politics of Identity (Minneapolis: University of Minnesota Press, 1992), 54.

${ }^{46}$ Jutta Weldes, "Constructing National Interests," European Journal of International Relations, forthcoming, 1996; National Interests: The Logic of U.S. National Security in the Postwar Era, unpublished Ph.D dissertation, University of Minnesota (1993).

${ }^{47}$ The term is used by Bill McSweeney in "Identity and Security: Buzan and the Copenhagen School," Review of International Studies, 22:1 (January 1996), 81-93. See Ole Waever, et al, Identity, Migration and the New Security Agenda in Europe (London: Pinter, 1993).
} 
problematic. "At its most basic social identity is what enables the word 'we' to be used" as a means by which to identify collectively the object to be secured. ${ }^{48}$ Research under this rubric has concentrated on the dynamic of European integration, the creation of a European "identity" by exclusion of the Russian or Turkish other, and the European response to "threats" posed to identities by migration (of guest workers, refugees, or illegal immigrants). ${ }^{49}$ It effectively "endogenizes" the questions of identities and interests, and challenges the rationalist idea that although identities may change, they do so over such a long time scale as to be irrelevant for most questions. By contrast, European identity can be shown to draw upon deeply held historical narratives, but to be adaptable and shifting in response to the concrete circumstances of the post-1945 (or even post-Cold War) period.

\section{Constructing Threats, Constructing Responses}

The second body of closely related literature inquires into how threats are defined and constructed. Again, a pure structural realist would find this question odd, for threats in a self-help system arise from the material capabilities of possible opponents. An amended version of this, as presented by Stephen Walt's "balance of threat theory," does appear to concede ground that is occupied by critical analyses. Walt argues that states balance not just against capabilities, but "against the states that pose the greatest threat," and threats are not objectively specifiable in the same sense that capabilities are, since they include offensive intentions. ${ }^{50}$ The world of threats and intentions, however, is supremely a constructed one, involving history, culture, communication, ideologies and related factors, and Walt's analysis does not tell us how or where threats (or their absence) arise, but takes for granted that they can (or should) be unproblematically perceived by decision-makers or scholars. ${ }^{51}$ By contrast, a critical approach would again ask: how, from the welter of information and interaction among states and their representatives, are threats constructed, and mobilized against?

Not surprisingly, most work here has focused on the American construction of the "Soviet threat." Bradley Klein's argument, based on an analysis of major documents of the early Cold War and

\footnotetext{
${ }^{48}$ Waever, et al, 17, see also Wendt, "Collective Identity Formation."

${ }^{49}$ See, Waever, et al; Iver Neumann and Jennifer Welsh, "The Other in European Self-identification," Review of International Studies 17 (1991), 327-48; Iver Neumann, "Russia as Europe's Other," unpublished paper, 1996.

${ }^{50}$ Stephen M. Walt, "Alliance Formation and the Balance of World Power," International Security 9 (1985), 9; The Origins of Alliances (Ithaca: Cornell University Press, 1987).

${ }^{51}$ See in particular, Walt's disagreement with Robert Kaufman over the nature of the Nazi threat in the 1930s, in Stephen M. Walt, "Alliances, Threats and U.S. Grand Strategy," Security Studies 1 (1992), 448-482; Robert Kaufman, "To Balance or to Bandwagon? Alignment Decisions in 1930s Europe," Security Studies 1 (1992), 417-447.
} 
creation of NATO, is that capabilities played hardly any role in the assessment of the Soviet threat: "what carried the day, in the absence of reliable intelligence estimates, was a series of discursively constructed claims about the nature of the Soviet totalitarian state and about its implacable global purposes." ${ }^{52}$ Jennifer Milliken's work on the Korean War highlights the effort that was involved, both within American policy circles and in the multilateral arena, to construct the North Korean invasion of the South as part of a Moscow-led aggressive expansionism, and not as an internecine struggle among Koreans. ${ }^{53}$ Both these works parallel some of the post-revisionist scholarship on the origins of the Cold War, that emphasize the effort that was involved in creating an American consensus over its international role. ${ }^{54}$ Simon Dalby's book challenges the inevitability of the "end of detente" and focuses on the construction of the Second Cold War. It analyzes the uses made by the American Committee on the Present Danger (and associated advocates) of geopolitical logic, historical determinism, and nuclear war-fighting logic to construct a series of interlocked arguments for the military build-up and European nuclear deployments that characterized the Reagan presidency. ${ }^{55}$

The post-Cold War threat environment has also provided extremely fertile ground for critical analysis, since the rhetorical nature of many threat discourses is evident. David Mutimer, for example, has examined in detail the metaphorical and linguistic construction of a "proliferation threat" for the United States (and its alliance partners). ${ }^{56}$ The elements of this have ranged from the efforts to dismantle the Iraqi nuclear, chemical and biological weapons programmes, to the conflict with North Korea over its possible nuclearization, to the creation of a "counter-proliferation" policy within the Clinton administration, and the resources devoted to such things as ballistic missile defence programs. One strand of feminist scholarship also falls under this umbrella. Cynthia Weber, for example, uses psychoanalytic theory to uncover the masculinized categories within which American intervention

\footnotetext{
${ }^{52}$ Bradley Klein, "How the West was Won: Representational Politics of NATO," International Studies Quarterly 34 (1990), 313. See also Charles Nathanson, "The Social Construction of the Soviet Threat: A Study in the Politics of Representation," Alternatives 13 (1988), 443-483.

${ }^{53}$ Jennifer Milliken, "Identity and Intervention: Reconstructing the West in Korea and the Balkans," in Jutta Weldes, Mark Laffey and Raymond Duvall, eds., Culture and the Production of Insecurity, forthcoming.

${ }^{54}$ See, for example, John Lewis Gaddis, Strategies of Containment (New York: Oxford University Press, 1982); Melvyn P. Leffler, A Preponderance of Power (Stanford: Stanford University Press, 1992).

${ }^{55}$ Simon Dalby, Creating the Second Cold War: The Discourse of Politics (New York and London: Guilford and Pinter: 1990).

${ }^{56}$ David Mutimer, "Reimagining Security: The Metaphors of Proliferation," in Krause and Williams, Critical Security Studies.
} 
practices in Panama (and elsewhere) were organized and justified. ${ }^{57}$ Nancy Hartsock and Carol Cohn have examined the way in which the "making" of soldiers invokes a range of gendered and masculinized concepts to permit the creation and control of social institutions of organized violence, or the way in which nuclear policies familiarize and "tame" the horror of nuclear weapons. ${ }^{58}$

Another line of research that is within the core subject matter of traditional security studies examines the way in which security policies constructed appropriate responses to the threats. Of course, often the construction of the threat and the response to it go together, but in principle research can be conducted on the latter without the former. Most attention here has focused on deterrence and arms control policies. For example, Emanuel Adler has charted the way in which the arms control "epistemic community" that emerged in the United States after the Cuban Missile Crisis charted a path out of the sterile debates over "disarmament" that had characterized previous thinking, and which generated cooperative security policies between the superpowers. ${ }^{59}$ Perhaps the most attention, however, has been devoted to the elaboration and implementation of nuclear deterrence policies, a frequent target for critical analysis. At the most straightforward level, this literature has drawn attention to "nukespeak" to the linguistic construction of the nuclear debate, and the ways in which weapons were "normalized" or opponents trivialized in order to promote particular nuclear deterrence policies. ${ }^{60}$ At a more conceptual level, scholars such as Michael Williams have attempted to uncover the paradoxical operation of the "logic of deterrence," locked into an oscillation between the twin poles of counterforce and counter-value strategies, the contradictions and tensions of each which generate the movement between the two. ${ }^{61}$ This analysis in fact situates deterrence theory (and policy) precisely as

\footnotetext{
57 "Something's Missing: Male Hysteria and the U.S. Invasion of Panama," Genders, 19 (1994), 171-197. There has also been some work (references not yet located) on the way in which the war against Iraq was constructed as a male confrontation between George Bush and Saddam Hussein. Weber's other work (which is not explicitly gender-related) also focus on the construction of interventionary practices. Simulating Sovereignty: Intervention, the State and Symbolic Exchange (Cambridge: Cambridge University Press, 1995).

${ }^{58}$ Cohn, "Sex and Death"; Nancy Hartsock, "Masculinity, Heroism and the Making of War," in Adrienne Harris and Ynestra King, Rocking the Ship of State: Towards a Feminist Peace Politics (Boulder: Westview Press, 1989), $133-152$.

${ }^{59}$ Emanuel Adler, "The Emergence of Cooperation: National Epistemic Communities and the International Evolution of the Idea of Nuclear Arms Control," International Organization, 46:1 (Winter 1992), 101-46.

${ }^{60}$ Examples include Paul Chilton, ed., Language and the Nuclear Arms Debate: Nukespeak Today (London: Frances Pinter, 1985); Cohn, "Sex and Death"; Timothy Luke, "What's Wrong with Deterrence?" A Semiotic Interpretation of National Security Policy," in James Der Derian and Michael Shapiro, eds., International/Intertextual Relations (Lexington: Lexington Books, 1989), 207-229.

${ }^{61}$ Michael C. Williams, "Rethinking the "Logic" of Deterrence," Alternatives, 17 (1992), 67-93. See also G.M. Dillon, "Modernity, Discourse and Deterrence," Current Research on Peace and Violence, 12:2 (1989), 90-104; Bradley Klein, Strategic Studies and World Order (Cambridge: Cambridge University Press, 1994), 106-122; Hugh Mehan, Charles
} 
an attempted rationalist response to what even Hans Morgenthau recognized as a "qualitative transformation of the meaning of our existence." ${ }^{62}$

All of these authors are concerned with how questions: how was an American or Western interest in opposing what was characterized as "Soviet expansionism" created and what forces did it mobilize, how did the language of nuclear deterrence operate as a powerful form to tame these weapons, and exclude particular options for dealing with them, or how do gendered (or more generally metaphoric) formulations construct "others" or sources of threats? The most common objection raised to all of this work is that these constructions operate as simple glosses on the interaction of the "real interests" that lie behind "the veil of facts." The response to this is a complex one, but all of these authors recognize that they need to challenge the orthodox neorealist argument that a confrontation between East and West was inevitable (which implicitly claims that the "why" question precedes the "how" question), that the construction of the Soviet threat was merely the public gloss on the operation of real interests in great power clashes, or that the particular form that this confrontation took was unimportant to an understanding of its causes and consequences. Hence, most of them pay particular attention to going beyond a demonstration of the constructed nature of threat discourses to show how these constructions could have been different, given the concrete historical circumstances in which choices were made. These are not "pure idealist" "if only" arguments.

\section{Society and Community under "Anarchy"}

A third axis of analysis for work in critical security studies has focused on the potential for "escaping" or overcoming the security dilemma. Needless to say, this approach is equally incomprehensible to neorealist scholarship, which posits the security dilemma as an axiomatic "given" of world politics; a logical consequence of the premises of autonomous actors seeking to survive in anarchy. The precise scope and acuteness of the security dilemma is subject to such factors as the nature of the offensedefence balance, but the underlying condition itself cannot be transcended ${ }^{63}$ Not surprisingly, scholarship that has challenged the unchanging nature of the security dilemma has not been met with open arms by the traditional literature.

\footnotetext{
Nathanson and James Skelly, "Nuclear Discourse in the 1980s: Unravelling the Conventions of the Cold War," Discourse and Society, 1:2 (1990) 133-165.

${ }^{62}$ Hans Morgenthau, "Death in the Nuclear Age," in Hans Morgenthau, Politics in the Twentieth Century, vol. 3 (Chicago: University of Chicago Press, 1960), 24-25.

${ }^{63}$ Robert Jervis, "Cooperation under the Security Dilemma," World Politics, 30:2 (1978), 167-214; Sean Lynn-Jones, "Offense-Defense Theory and its Critics," Security Studies, 4:4 (Summer 1995), 660-691.
} 
Several lines of argument can be discerned here, however. The first, which is not "critical" in the sense outlined above, has made various adjectival modifications to "security," under the heading of "collective," "common," "comprehensive," or "cooperative" security. ${ }^{64}$ With the possible exception of collective security, these arguments argue for an amelioration, not a "transcending," of the security dilemma. As David Dewitt has noted, "the intent has been to replace the cold war security structure...with a multilateral process and framework with the following attributes: it must be geared toward reassurance, rather than deterrence; it must at best replace or at least co-exist with bilateral alliances; and it must promote both military and non-military security ${ }^{65}$ Hence the most prominent advocates of "cooperative security" have argued that it requires "a commitment to regulate the size, technical composition, investment patterns, and operational practices of all military forces by mutual consent for mutual benefit" which "involv[es] extensive agreed-on constraints on military preparations [that] would have to require all parties to accept a level of intrusive monitoring of their defense programs." ${ }^{66}$ But in more "theoretical" terms, these arguments operate under the general umbrella of the neorealist-neoliberal debate, and do not present a critical analytic challenge to it.

A more interesting line of research, convincingly presented by scholars such as Daniel Deudney or Emanuel Adler, examines the potential for overcoming anarchy through the creation of "security communities." Deudney, for example, argues that the "Philadelphian system" of the American union between 1787 and 1861 was neither a "real-state" (enjoying a monopoly of violence, for example), nor a competitive system of states. Instead, it was a conscious alternative: "the designers of the Philadelphian system understood the dynamics of anarchy, but the interstate anarchy of Europe was a model of what they sought to avoid, not an inevitability to which they sought to adjust...[hence] anarchy can be overcome under certain conditions." ${ }^{67}$ Deudney recognizes that this implies a rethinking of security, especially in contemporary contexts such as the European Union. This theme is taken up by Adler, who draws attention to the way in which regionalization processes in the European Union, North

\footnotetext{
${ }^{64}$ On collective security see Charles and Clifford Kupchan, "Concerts, Collective Security, and the Future of Europe," International Security, 16 (Summer 1991), 114-161; Andrew Hurrell, "Collective Security and International Order Revisited," International Relations (1992), 37-55; on common security see The Independent Commission on Disarmament and Security Issues (Palme Commission), Common Security: A Blueprint for Survival (New York: Simon and Schuster, 1992).

${ }^{65}$ David Dewitt, "Common, Comprehensive and Cooperative Security," The Pacific Review, 7:1 (1994), 2.

${ }^{66}$ Ashton Carter, William Perry and John Steinbrunner, A New Concept of Cooperative Security (Washington: The Brookings Institution, 1992), 6, 36, 38-39.

${ }^{67}$ Daniel Deudney, "The Philadelphian System: Sovereignty, Arms Control, and Balance of Power in the American States-Union, circa 1787-1861," International Organization, 49:2 (Spring 1995), 225, 191-228.
} 
America, the Southern Cone, the OSCE, and perhaps Southern Africa "point in the direction of a change in the ways in which political, economic, and cultural elites conceptualize international relations." ${ }^{68}$ His work explicitly revives Karl Deutsch's concept of "pluralistic security communities," but moves beyond its somewhat functionalist focus on such things as transaction flows, towards more cognitive (and evolutionary) elements such as learning, stable expectations, shared practices, or identification of common self-images. ${ }^{69}$

Parallel to this would be Bradley Klein's work on the creation of the Western Alliance, which emphasizes the way in which "the West has constituted itself as a political and cultural identity" to be secured. ${ }^{70}$ His work can be usefully contrasted to both neo-realist and neoliberal accounts: a neorealist prediction (insofar as it is capable of offering one) for post-Cold War NATO would be of weakening and perhaps dissolution or disintegration; a neoliberal account would emphasize the possibility of institutional inertia and the continued utility of NATO for lowering transaction costs and easing collaboration problems between Western states. ${ }^{71}$ By contrast, his critical analysis focuses on the possibilities for perpetuating a discursive "community of interests" as the sine qua non for avoiding conflicts and maintaining a zone of peace. From an explicitly feminist perspective, Simona Sharoni examines the role of Palestinian and Israeli women in that conflict, and draws attention both to the ways in which discourses (and practices) of "citizenship" and "nationalism" are constructed to become a primary identity that "drowns out" (perhaps in the name of mobilizing the state for war" other identity relationships, and the practical implications of various attempts to overcome this. ${ }^{72}$

A third, more methodologically-oriented, analysis is presented by scholars such as Karen Fierke or Ole Waever. Waever situates security studies within the context of "speech acts": his research goal is to study the process by which threats are represented politically, to examine "who can 'do' or 'speak' security successfully, on what issues, under what conditions, and with what effects...what is

\footnotetext{
${ }^{68}$ Emanuel Adler, "Imagined (Security) Communities," unpublished paper, April 1994, 6-7.

${ }^{69}$ For the original statement, see Karl Deutsch, et al, Political Community and the North Atlantic Area (Princeton: Princeton University Press, 1957); see also Emanuel Adler, "Europe's New Security Order: A Pluralistic Security Community," in Beverly Crawford, ed., The Future of European Security (Berkeley: University of California, Center for German and European Studies, 1992), 287-326.

${ }^{70}$ Klein, "How the West was Won," 311.

${ }^{71}$ John Mearsheimer, "Back to the Future: Instability in Europe after the Cold War," International Security 15 (1990), 556; Gunther Hellmann and Reinhard Wolf, "Neorealism, Neoliberal Institutionalism, and the Future of NATO," Security Studies 3:1 (Autumn 1993), 3-43.

${ }^{72}$ Simona Sharoni, Gender and the Israeli-Palestinian Conflict (Syracuse: Syracuse University Press, 1995).
} 
essential is the designation of an existential threat...and the acceptance of that designation by a significant audience." 73 This audience need not be "national," and in fact some of the most interesting acts of "speaking security" are those used to define the broader communities of identity. Fierke takes up this theme in her detailed case study of the "grammar" of representation of the Western community (within Western Europe and NATO) and its relationship with the East (especially with Eastern European dissident movements) during the waning stages of the Cold War. Her goal is to examine the "demise of a particular constellation of relationships and practices," as a means to uncover the reconstructive potential that will shape the future of the European security order. ${ }^{74}$

\section{Disciplining Practices}

Traditional scholarship in security studies has responded to the challenges posed by the different threads of critical scholarship outlined above through a series of what could be called "disciplining practices," which I have labelled "cooptation," "exclusion," "character assassination," and "definitional fiat." I am not claiming that these practices are part of a malicious or conspiratorial program to keep the "critical" from contaminating security studies. I am, however, arguing that the consequence of these practices is a severe constriction of what we can study and how we can study it that serves neither scholarship nor practical politics.

The first disciplining move, cooptation, has been manifest most clearly within security studies in the rapid slide from "strategic studies" to "security studies" as the label or umbrella for the field. One position in this debate argues that strategic and security studies are distinct, and that the latter ought to expand the categories and areas of analysis considerably beyond the traditional purview of the former. Strategic studies should, on this account, retain its more narrow purpose and scope - a body of expertise on the military aspects of international relations - while being embedded within the broader ambit of security studies. As Barry Buzan, the most prominent exponent of this view, admits, however, this position is in the minority. ${ }^{75}$ Rather, the majority position has argued that the proper umbrella or title

\footnotetext{
${ }^{73}$ Ole Waever, Security Analysis: Conceptual Apparatus. In "Environmental, Economic and Societal Security." Working Papers 10, by Barry Buzan, Ole Waever and Jaap de Wilde. Copenhagen: Centre for Peace and Conflict Research, 1995, 4.

${ }^{74}$ See Karen Fierke, "Changing Worlds of Security." in Krause and Williams, eds., Critical Security Studies; Dismantling the Cold War, unpublished book manuscript, 1995.

${ }^{75}$ Barry Buzan, People, States and Fear, second edition (London: Harvester Wheatsheaf, 1991), 23-25. This also might be the position of Baldwin, who argues for the dissolution of "security studies" into international relations and foreign policy. Baldwin, "Security Studies and the End of the Cold War."
} 
should be "security studies," but that it should retain a relatively narrow (or only slightly enlarged) understanding of its scope and purpose. This position is staked out by scholars such as Stephen Walt, Joseph Nye, or Sean Lynn-Jones. ${ }^{76}$ Nye and Lynn-Jones draw the line clearly: "a subject that is only remotely related to central political problems of threat perception and management among sovereign states would be regarded as peripheral."17 The implication, however, is that the methods, focus and orientation of "strategic studies" should be carried over into this new realm, effectively defining away broader conceptions of "security studies." As Buzan puts it, this "would be like giving responsibility for designing a national transportation system to the makers of automobiles."18

The practical exclusionary consequences of this are easy to find. Mark Levy, for example, in his review of the environment and security literature, characterizes these views as "existential" visions of the link between environment and security. He concedes the importance of ecological hazards to human well-being, but argues that the work is marked more by a desire to heighten the political profile of environmental issues by placing them within the rhetoric of security than by any sustainable status as "security issues." ${ }^{179}$ Likewise, Robert Dorff argues that although a broader definition of security highlights significant contemporary "problems," these do not constitute "security" issues because "problems' is not a concept...[it] provides us with no ordering of reality that we can use to create a common understanding of what it is that we are talking about and the range of possible policy approaches to addressing those problems." ${ }^{10}$ But by treating the broadening of the concept of security as a "political" rather than analytical move, the traditional view is positioned as an apolitical analytic

\footnotetext{
${ }^{76}$ See Stephen Walt, "The Renaissance of Security Studies," International Studies Quarterly, 35 (1991), 211-239; Joseph Nye and Sean Lynn-Jones, "International Security Studies: A Report of a Conference on the State of the Field," International Security, 12 (1988), 5-27; Richard Schultz, Roy Godson, and Ted Greenwood, eds., Security Studies for the 1990s (New York; Brassey's, 1993).

${ }^{77}$ Nye and Lynn-Jones, 7. Their argument for eschewing the previous label is that "the name strategic studies...might exclude some of the more basic theoretical questions about the causes of war or the relationship between international economics and international security."

${ }^{78}$ Buzan, 23. A more complex variant of cooptation is methodological: the attempt to bridge the gap between so-called "quantitative" and "qualitative" methodologies by incorporating the former into the latter. This approach is adopted by Gary King, Robert O. Keohane and Sidney Verba, Designing Social Inquiry: Scientific Inference in Qualitative Research (Princeton: Princeton University Press, 1994). Needless to say, for critical scholars this misses the point. See Charles Taylor, Philosophical Papers, vols. 1 and 2 (Cambridge: Cambridge University Press, 1985).

${ }^{79}$ Marc A. Levy, "Is the Environment a National Security Issue?" International Security 20:2 (Fall 1995), 35-62; "Time for a Third Wave of Environment and Security Scholarship," Environmental Change and Security Project Report, Woodow Wilson Center, 1 (19950, 44-46.

${ }^{80}$ Robert H. Dorff, "A Commentary on Security Studies for the 1990s As a Model Core Curriculum," International Studies Notes 19 (1994), 27. See also Colin Gray, Villains, Victims and Sheriffs: Security Studies and Security for an Inter-War Period (Hull: University of Hull Press, 1995).
} 
stance that is not equally driven by (or established upon) a set of value commitments. As a result, alternative conceptions of security are judged by how well they fit within and contribute to the (purportedly objective) prevailing categories of the field - a concern with inter-state violent conflict. Not surprisingly, the answer turns out to be that they are not really security issues at all. Although Levy admits it is possible to conceive of "global security," he defines security as "national security" - as a situation where threats to a "nation's most important values" come from the actions of "foreigners." 81 But adopting the taken-for-granted political resolutions of orthodox security studies is not a neutral point against which alternative conceptions can be judged.

The third disciplining move, character assassination, is by far the most difficult to pin down (and avoid polemics). I think, however, that it is not difficult to agree with Wendt that Mearsheimer's "discussion of [critical theorists'] research program [is] full of conflations, half-truths, and misunderstandings." 82 The goal of critical security studies is not to make "states, or more precisely, their inhabitants and leaders...care about concepts like 'rectitude,' 'rights,' and 'obligations'"; its scholars are not naively committed to "replac[ing] realism with a discourse that emphasizes harmony and peace"; they are not "intolerant of other discourses about international politics" (except perhaps when they themselves are not taken seriously as scholars); and the phrase "intersubjective understandings and expectations" is not "jargon" (any more than any conceptual language) ${ }^{83}$ Of course, individual scholars may be guilty of turgid prose, or can be committed to one or another vision of a desirable future world - just as Mearsheimer doubtless is - but this is not (as noted above) the core of the project. Finally, as I hope this paper amply demonstrates, the distinguishing feature of critical security studies literature is not its lack of empirical content.

A more interesting version of this argument is presented by Stephen Walt, when he argues that while it is important to permit additions or amendments to the orthodox core of security studies, to

\footnotetext{
${ }^{81}$ Levy, "Is the Environment a National Security Issue?" 40-1.

${ }^{82}$ Wendt, "Constructing International Politics," 71.

${ }^{83}$ Mearsheimer, "False Promise," 39, 41, 43. His most egregious example of character assassination is worth quoting in full:

Most critical theorists do not see ideas and discourses forming at the grass roots and then percolating up to the elites of society. Rather, theirs is a top-down theory, whereby elites play the key role in transforming language and discourse about international relations. Experts, especially

scholars, determine the flow of ideas about world politics. It is especially useful, however, if this intellectual vanguard consists of individuals from different states. These transnational elites, which are sometimes referred to as "epistemic communities," are well-suited for formulating and spreading the communitarian ideas that critical theorists hope will replace realism ("False Promise," 41).

The Mcarthyist tone is inescapable, and unforgivable.
} 
challenge fundamentally its foundations is intellectually self-indulgent and even perhaps politically irresponsible. As he says, "issues of war and peace are too important for the field to be diverted into a prolix and self-indulgent discourse that is divorced from the real world." ${ }^{84}$ One response from the critical camp is that the charge of political irresponsibility rests more strongly on those who place scholarship at the service of the state, or who attempt to uncover transhistorical generalizations at such a high level of abstraction that they eschew engagements with practical political problems (or which, if true, deny any scope for human agency). ${ }^{85}$

The final disciplining practice, argument by definitional fiat, is most evident in the nearlytautological assertions of the nature of world politics over the past several hundred years of human history. Several examples have been noted above, ranging from the blanket assertion that inter-state relations over the past several centuries can be captured by simple models of self-interested balancing or bandwagoning behaviour, or that deductive logic can be used to "prove" that states pursue relative over absolute gains. ${ }^{86}$ A contemporary manifestation of this appears in attempts to incorporate nationalism into security studies, either by treating identity groups as "given" unitary rational actors, or by explaining the rise of nationalism as a tactical choice for political entrepreneurs. ${ }^{87}$ Neither approach actually "theorizes" nationalism. The first leaves aside all the interesting questions about how (under what circumstances, with what consequences) such groups emerge and differentiate themselves, and treats "nationalism" as mere rhetoric; the second ignores the consequences of this rhetorical choice for the construction of threats (who or what is threatened, by whom, and in what manner), and projects nationalism solely through the prism of interstate relations. Neither provides an adequate understanding of the complex forces at work in contemporary communal conflicts, or for potential points of resolution

\footnotetext{
${ }^{84}$ Walt, "Renaissance," 223. See also 213.
}

${ }^{85}$ As Thomas Christensen and Jack Snyder point out, structuralist explanations do not in themselves permit "determinate predictions at the foreign policy level," without the addition of factors such as intentions, beliefs, and perceptions. Of course, these are precisely the sorts of issues that constructivists take up, and neorealist scholars run into deep methodological trouble when they assert that "domestic and perceptual forces can be cleanly plugged into parsimonious international system theories." See Thomas Christensen and Jack Snyder, "Chain Gangs and Passed Bucks: Predicting Alliance Patterns in Multipolarity," International Organization 44 (1990), 138, 144; and for a critique, Krause and Williams, "Politics and Method."

${ }^{86}$ On this last point, see Grieco, "Anarchy," and for an insightful rejoinder, Robert Powell, "Absolute and Relative Gains in International Relations Theory," American Political Science Review, 85:4 (December 1991), 1303-1320, in which he argues that "the question of whether states maximize absolute gains or are concerned about relative gains is empirically meaningless." (p. 1316). Although I do not agree that the real question is the "utility" of the assumption for generating predictions, Powell at least detects the pointlessness of the debate.

${ }^{87}$ Barry Posen makes both these moves in "Nationalism, the Mass Army and Military Power," International Security 18:2 (Fall 1993), 80-124; "The Security Dilemma and Ethnic Conflict," Survival, 35:1 (Spring 1993), $27-47$. 
and exit from them. One has to step outside of the neorealist paradigm in order to pose the sorts of questions whose answers have, in today's world, inescapably concrete consequences. ${ }^{88}$

\section{Conclusion: Powerful Problematics}

My goal in this paper has been to deflect the criticism that little empirical research has been done by critical security studies scholars, and to demonstrate the diverse and rich threads of the critical research agenda. This is not, however, meant as an unabashed defence or apologia of all of the scholarship in this area, much of which does not live up to the terms of its epistemological and ontological foundations. In fact, as Charles Taylor has pointed out, if scholars took seriously the requirements of interpretivism, there would probably be a considerable thinning of its ranks! But critical security studies scholarship is surely no worse in this respect than the corpus of security studies as a whole.

A final task of any critical approach to security studies would be to give an interpretive account of the resilience and attraction of rationalist or neorealist conceptions of security. This will have to be deferred for another paper, but I can at least point out that such an account would follow in the tracks of scholars such as Azar Gat and John Shy, who have argued that the search for the "laws of war" goes back at least to the Enlightenment, and that this vision of truth and method "has become, during almost two centuries, so deeply embedded in Western consciousness that many adherents refuse to accept it as a 'mode' of thinking at all." 89 The issue is not one of bad faith, false consciousness or power plays in the scholarly community (although all can and do exist), but rather of how rationalist accounts resonate within broader conceptions of theory and purpose for social sciences. Likewise, the metaphorical force of the Hobbesian "state of nature" and its contractarian account of world politics must be acknowledged, especially since it presents a powerful resolution to old and thorny questions of political life. The challenge is to ensure that our theoretical conceptions of what is possible and desirable are not bound within rigid intellectual straightjackets that place us far behind policy-makers' (and other political actors) appreciation of the complexities and potential of the contemporary world, or that

\footnotetext{
${ }^{88}$ Yosef Lapid and Friedrich Kratochwil, "Revisiting the "National": Toward an Identity Agenda in Neorealism?," in Yosef Lapid and Friedrich Kratochwil, eds., The Return of Culture and Identity in IR Theory (Boulder: Lynne Reinner, 1996), 105-126. For a study of how the construction of the causes of the war in the former Yugoslavia were linked to particular understandings of the (im)possibility of intervening, see Beverly Crawford and Ronnie Lipschutz, "Discourses of War: Security and the Case of Yugoslavia," in Krause and Williams, Critical Security Studies.

${ }^{89}$ See Azar Gat, The Origins of Military Thought (Oxford: Oxford University Press, 1989), 29, 25-53; The Development of Military Thought: The Nineteenth Century (Oxford: Clarendon Press, 1992), 1-45; John Shy, "Jomini," in Peter Paret, ed., Makers of Modern Strategy (Oxford: Clarendon Press, 1986), 184-85.
} 
prevent us from thinking creatively and seriously about resolutions to complex contemporary problems of war and peace. 